\title{
Intralingual Translation as an Option for Radical Spanglish
}

\author{
Remy Attig \\ University of Ottawa
}

Since the 1990s literary production in Spanglish, the so-called "hybrid" language that mixes English and Spanish, has been increasing. With increasing publication has come a demand for translations of these texts. While some authors readily choose to translate their work, others are closer in line with Gloria Anzaldúa who said "Until I can take pride in my language I cannot take pride in myself... Until I am free to write bilingually and to switch codes without having always to translate, while I still have to speak English or Spanish when I would rather speak Spanglish, and as long as I have to accommodate the English speakers rather than having them accommodate me, my tongue will be illegitimate" (1999, 81). This hesitation to accommodate English speakers fails to consider that approximately $2 / 3$ of them are non-native speakers. Consequently, the role that English can play in south-to-south translation is not negligible and "having" to translate because of the existing English hegemony in the US Latinx context is not the same as choosing to translate for any of a number of other motivating factors. Both are equally legitimate options, but this begs the question, is there a way to translate Spanglish so that English readers can access it without "accommodating" the English hegemony? This paper explores intralingual translation rather than normative interlingual translation as a tool to expand the readership of these texts while not fully assimilating them into the traditional English publication norms. 